\title{
Environmental Consequences of Oil Blowout from Subsea Pipeline, A Case Study in the Persian Gulf
}

\author{
Mehdi Shafieefar ${ }^{1}$, Pooya Ranjbar ${ }^{2}$
}

\begin{abstract}
Modeling of oil blowout from the Khark island pipelines in the Persian Gulf has been carried out to evaluate environmental consequences including the oil pollution effects on the coast, seabed and most importantly Khark area aquatic, the prawns. The analyses have been carried out with the SINTEF Oil Spill Contingency and Response (OSCAR) 3-dimensional model system. Results related to scenarios demonstrate that wind is the major agent for advection and spreading of oil in the area. Due to wind conditions in Khark area, the Khark South-East coast has the maximum oil contamination potential. A significant part of the oil will pollute the environment by dispersing in the water column, being deposited on the seabed and hitting the Khark coast. In conclusion, the hypothetical spilled oil extremely threats the Khark area environment and specially the prawns.
\end{abstract}

Keywords - Oil Spills, Response Action, Pipelines, Prawn, Persian Gulf.

\section{INTRODUCTION}

$\mathrm{O}^{\prime \prime}$ IL is a vital production for modern society. However, this resource can destroy marine life, economy and environment if becomes out of control and can be one of the most destructive pollutant substances for the environment. Many countries have a contingency plan for prevention of pollution due to oil spill in the sea environment. Numerical models are used to predict the movement and distribution of oil particles concentration in the water.

The Persian Gulf has the most oil resources and oil transport activities in the world. Due to a large number of oil resources and heavy tanker traffic, the potential for oil pollution is high. Elhakeem et al. (2007) presented the results of simulation of Al-Ahmadi historical oil spill crisis in the Persian Gulf using MIKE3-SA. They employed a 3-D rectilinear hydrodynamic model combined with oil spill model. Proctor et al. (1994) used a three-dimensional model to simulate fate of oil spills of Al-Ahmadi in Kuwait. Farzingohar et al. (2011) used GNOME model for simulating oil spill in Hormozgan waters. Lehr et al. (1979) used GULFSLIK I model for simulating oil spill trajectory in Persian Gulf, Saudi Arabia. Farzingohar et al. (2011) used GNOME model for simulating oil spill in Hormozgan waters. Lehr et al. (1979) used GULFSLIK I

Mehdi Shafieefar ${ }^{1}$ is with the Faculty of Civil and Environmental Engineering, Tarbiat Modares University, Tehran, Iran

Pooya Ranjbar ${ }^{2}$ is graduated student of Tarbiat Modares University, Tehran, Iran. model for simulating oil spill trajectory in Persian Gulf, Saudi Arabia. Howlett et al. (2008) used OILMAP model to forecast oil spill in Dubai region of Persian Gulf.

Al-Rabeh et al. (1991) used both GULFSLIK II and OILPOL models to simulate the fate of oil spills of Al-Ahmadi in Kuwait. Sabbagh Yazdi (2006) presents a coupled solution of oil slick and depth averaged tidal currents near Siri Island, Persian Gulf. Badri et al. (2010) present an oil spill model based on the Kelvin wave theory and artificial wind field for Northern part of the Iranian waters of Persian Gulf. Ranjbar $e t$ al. (2013) present analyses of specific hypothetical blowout scenarios related to subsea oil pipelines between the coast of mainland of Iran and Khark island in the Persian Gulf to evaluate of planed response actions and strategies for decreasing environmental consequences of spilled oil on Khark island area.

This study is an objective basis for analyses of planed response actions and strategies for decreasing environmental consequences of spilled oil on Khark area. A scenario-specific modeling has been carried out to evaluate potential effects due to oil spill from pipelines which are located on the seabed between Iran mainland coast and Khark Island (Fig. 1). The scenarios are selected in a way to represent a practical analysis for the evaluation of environmental consequences including the potential oil pollution effects on the area coast, seabed and most importantly Khark area aquatic, the prawns and to determine the efficiency of contingency planning.

Subsea oil blowout and its movement to the surface behaves as a jet (due to momentum and buoyancy) or a plume (due to buoyancy) has been modeled by DEEPBLOW which is embedded in OSCAR model. Material \& Methods

\section{KHARK ISLAND PIPELINE}

Khark Island is the biggest oil export terminal of Iran and is located approximately $57 \mathrm{~km}$ North-West of Boushehr and 40 $\mathrm{km}$ South of Genaveh port (Fig.1). Approximately $90 \%$ of crude oils of Iran is transported to Khark Island from the mainland and offshore oil fields by 5 pipelines, and exported from there. The mean water depth in this area is approximately $20 \mathrm{~m}$ (Khark Database, 2011). This area has a high potential of oil blowout from pipelines due to probable events such as earthquake and corrosion. Modeling of hypothetical oil spills have already been carried out by OSCAR 3-Dimensional model by Ranjbar et al (2013). OSCAR model system has 
been developed to supply a tool for objective analysis of alternative spill response strategies, (Reed et al., 1995a; Aamo et al., 1996).

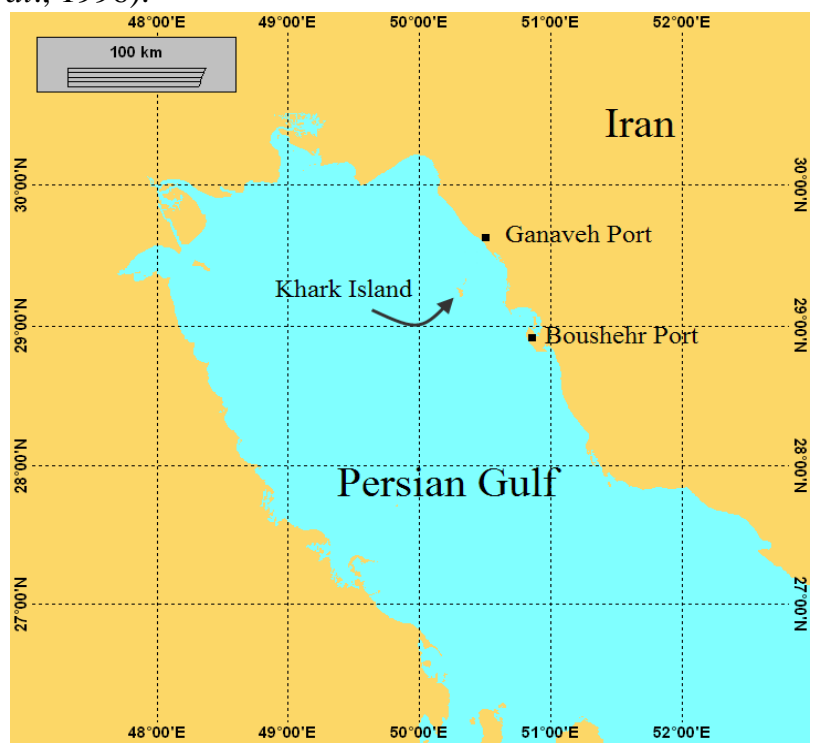

Fig. 1 Location map for application of OSCAR for Khark pipelines

The dominant currents in the Persian Gulf are tidal currents. Simulation of the tidal current in the Persian Gulf is performed by hydrodynamic module of MIKE21 model (DHI, 2007) called MIKE21-HD, and simulation of subsurface winddriven currents is performed by Ekman model (Reed et al., 1999) which is embedded in OSCAR model.

The dominant wind direction in Khark area is North-West toward South-East with an average speed of $4 \mathrm{~m} / \mathrm{sec}$ in January. For wind input (speed and direction), the atmospheric model data from ECMWF ${ }^{1}$ website is used. In this study, input data are prepared with a grid size of $2.5^{\circ}$ by $2.5^{\circ}$, and are chosen from ECMWF 40 Years (Re-Analysis - Synoptic Monthly Mean). The wind data cover the period from January 02, 1994 to February 01, 1994 with 6 hours time step. In January, average water column temperature is $16{ }^{\circ} \mathrm{C}$, air temperature is $30{ }^{\circ} \mathrm{C}$, averaged water column salinity is 35 $\mathrm{gr} / \mathrm{lit}$ and averaged water column oxygen is $10 \mathrm{mg} / \mathrm{l}$ (Khark Database, 2011).

The definition of the coastline is limited by the spatial resolution of the underlying map data. The coastal data supplied with the model has a resolution of approximately 1 $\mathrm{km}$. The dataset is derived from the United States Defense Mapping Agency's digital chart of the world (DCW) database. Bathymetry is defined by one or more gridded datasets, stored in a database supplied with the OSCAR model. The dataset supplied with the model, SeaTopo 6.2, covers from 72 degrees $\mathrm{S}$ to 72 degrees $\mathrm{N}$ latitude, provides a resolution of 3 to $10 \mathrm{~km}$, and is based on a combination of satellite altimetry and ship soundings by Smith and Sandwell, 1994, 1997 (Reed et al. 2011).

The main protected areas include the spawning areas and nursery grounds of green tiger prawn. Green tiger prawn plays an important role in aquatic ecosystem of the region. It is considered as the finest aquatic of Khark area because of its high cost. In addition, this kind of prawn is directly included in the human food chain, so evaluation of the potential pollution effects on this aquatic is important. Nearby the source, there are three areas that are most productive. They are distributed in the depth of 20-30 meters and have the potential for exposure to oil pollution. These areas include Genaveh area (area \#1), Hele area (area \#2), and Boushehr area (area \#3) that are shown in Fig. 2. Winter is the most important spawning season for the green tiger prawn, and the hypothetical oil blowout occurs in this season (Niamaimandi, 2011). Mentioned areas are considered to satisfy operational criteria and evaluate the efficiency of the oil spill response operation.

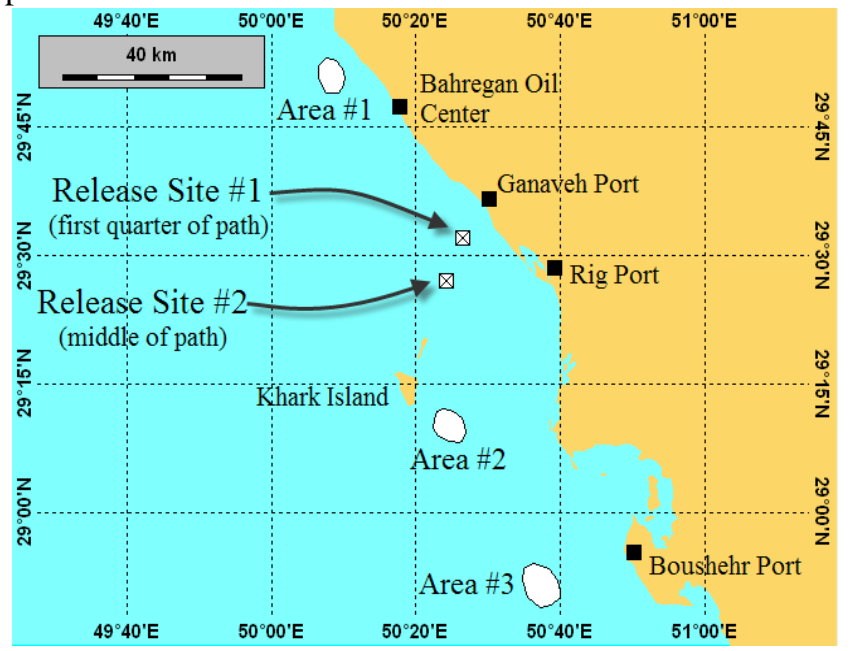

Fig. 2 Protected areas and release sites are specified

OSCAR allows the assignment of specific operational strategies to each boom-skimmer or dispersant vessels system being simulated. Characteristics of boom-skimmer systems, dispersant vessels and dispersant aircraft which owned by HSE department of Khark area and used in response action are outlined in

Table and Error! Reference source not found. respectively. It is assumed that recovery efficiency is dependent on significant wave height. In OSCAR, it is computed as a function of wind speed, fetch and duration. Under ideal condition a maximum of $80 \%$ of the oil entering the boom can be recovered, with the remaining leaking under the boom. Effectiveness is reduced as wave height (or wind speed) increases, and goes to zero at 2 meter wave height, or a wind speed a little over $10 \mathrm{~m} / \mathrm{sec}$ ( 20 knots). It is further assumed that operations cease at night (i.e. that infrared monitoring equipment is not available). OSCAR computes sunrise and sunset from latitude and longitude and calendar day (Aamo et al., 1995, 1996). The response action equipments that have a mobilization time equal to 2 hours are located in Khark Island and the others are not. 
TABLE I

DESCRIPTIVE PARAMETERS OF BOOM-SKIMMER SYSTEMS WHICH OWNED BY HSE DEPARTMENT OF KHARK AREA (KHARK DATABASE, 2011)

\begin{tabular}{|l|c|c|c|c|c|c|c|}
\hline \multicolumn{1}{|c|}{ System } & $\begin{array}{c}\text { Mobiliza } \\
\text { tion } \\
\text { (h) }\end{array}$ & $\begin{array}{c}\text { Cruisi } \\
\text { ng speed } \\
\text { (knots) }\end{array}$ & $\begin{array}{c}\text { Operatio } \\
\text { nal } \\
\text { speed } \\
\text { (knots) }\end{array}$ & $\begin{array}{c}\text { Boom } \\
\text { opening }(\mathrm{m}\end{array}$ & $\begin{array}{c}\text { Nominal } \\
\text { skimmer } \\
\text { capacity } \\
\left(\mathrm{m}^{3} / \mathrm{h}\right)\end{array}$ & $\begin{array}{c}\text { Storage } \\
\text { capacity }\left(\mathrm{m}^{3}\right)\end{array}$ & $\begin{array}{c}\text { Maximum } \\
\text { operational } \\
\text { wave height } \\
(\mathrm{m})\end{array}$ \\
\hline $\begin{array}{l}\text { First boom-skimmer } \\
\text { systems (1) }\end{array}$ & 2 & 12 & 2 & 100 & 30 & 30 & 2 \\
\hline $\begin{array}{l}\text { Second boom-skimmer } \\
\text { systems (1) }\end{array}$ & 48 & 12 & 2 & 100 & 30 & 30 & 2 \\
\hline $\begin{array}{l}\text { Third boom-skimmer } \\
\text { systems (1) }\end{array}$ & 2 & 12 & 2 & 250 & 40 & 40 & 2 \\
\hline
\end{tabular}

TABLE II

DESCRIPTIVE PARAMETERS OF DISPERSANT APPLICATION WHICH OWNED BY HSE DEPARTMENT OF KHARK AREA (KHARK DATABASE, 2011)

\begin{tabular}{|c|c|c|c|}
\hline System & $\begin{array}{c}\text { Aircraft } \\
\text { (1) }\end{array}$ & $\begin{array}{c}\text { Vessel Type } \\
1(2) \\
\end{array}$ & $\begin{array}{c}\text { Vessel Type } \\
2 \text { (1) } \\
\end{array}$ \\
\hline $\begin{array}{l}\text { Application rate } \\
\left(\mathrm{m}^{3} / \mathrm{min}\right)\end{array}$ & 0.9 & 0.5 & 0.5 \\
\hline Mobilization time (hr.) & 48 & 2 & 2 \\
\hline Dispersant tankage $\left(\mathrm{m}^{3}\right)$ & 5 & 2.7 & 2 \\
\hline $\begin{array}{l}\text { Operational wind } \\
\text { threshold (knot) }\end{array}$ & 30 & - & - \\
\hline Cruise speed (knot) & 280 & 10 & 12 \\
\hline $\begin{array}{l}\text { Operational speed } \\
\text { (knot) }\end{array}$ & 140 & 2 & 2 \\
\hline Endurance (hr.) & 4 & - & - \\
\hline Spray width (m) & 25 & 10 & 10 \\
\hline No. of trips pr. day & 5 & 10 & 10 \\
\hline $\begin{array}{l}\text { Total available } \\
\text { dispersant }\left(\mathrm{m}^{3}\right)\end{array}$ & 100 & 100 & 100 \\
\hline Effectiveness (\%) & 70 & 70 & 70 \\
\hline $\begin{array}{l}\text { Turnaround time to } \\
\text { refilling (hr.) }\end{array}$ & 1 & 0.5 & 0.5 \\
\hline Dispersant type & $\begin{array}{c}\text { Superdispe } \\
\text { rsant- } 25 \\
\text { type } 2\end{array}$ & $\begin{array}{l}\text { Superdispersa } \\
\text { nt-25 type } 2\end{array}$ & $\begin{array}{c}\text { Superdispersa } \\
\text { nt-25 type } 2\end{array}$ \\
\hline
\end{tabular}

There are three mechanical recovery equipment systems in response contingency planning. Two systems can be mobilized in 2 hours and one system can be mobilized in 48 hours after announcing the accident. Two recovery systems have a boom with 100 meters length and a skimmer with $30 \mathrm{~m}^{3} / \mathrm{hr}$ pumping capacity, and another recovery system has a boom with 250 meter length and a skimmer with $40 \mathrm{~m}^{3} / \mathrm{hr}$ pumping capacity are considered. In addition, there are three vessels which contain chemical dispersant with application rate of 0.5 $\mathrm{m}^{3} / \mathrm{min}$ and there is an aircraft which contains chemical dispersant with application rate of $0.9 \mathrm{~m}^{3} / \mathrm{min}$. Mentioned systems by dispersal of oil slicks into water column particle, can significantly decrease the potential of surface oil potential. Mobilization time of vessels is 2 hours and mobilization time of aircraft is 48 hours after announce the accident. Limitation in using chemical dispersant should be considered. Chemical dispersant should be used when the cleaning of oil from the surface is important and oil into the water column has no bad effect on the environment. Therefore use of chemical dispersant needs an accurate investigation.

A scenario of one-month blowout from a hole with $2.5 \mathrm{~cm}$ diameters in any point of the pipelines will certainly hit the coast. If a hole with $5 \mathrm{~cm}$ diameter is created at any point of the pipelines, and it continues to exist for 1 day, spilled oil definitely reaches to the coast. The minimum diameter of probable hole is considered to be $5 \mathrm{~cm}$ and probable seabed blowout is assumed to occur between $1 / 4$ to $3 / 4$ of the pipeline length, because the water depth outside this range is quite shallow.

Two Pipelines (one 30 inches OD (outside diameter) and one 52 inches OD) transport the Iranian heavy crudes and three Pipelines (two 30 inches OD and one 42 inches OD) transport the Iranian light crudes between Genaveh port and Khark Island with a length approximately equal to $46 \mathrm{~km}$. The density of light and heavy oil is $0.852 \mathrm{ton} / \mathrm{m}^{3}$ (in temperature of $21{ }^{\circ} \mathrm{C}$ ) and $0.875 \mathrm{ton} / \mathrm{m}^{3}$ (in temperature of $21{ }^{\circ} \mathrm{C}$ ) respectively (Khark Database, 2011). Hypothetical blowout from three pipelines including 30 inches OD light oil, 30 inches OD heavy oil and 52 inches OD heavy oil is separately investigated for both the light and the heavy crude oil.

The oil transportation is between a station in the vicinity of Genaveh port and a station in Khark Island. Pressure at the Genaveh port station is equal to $280 \mathrm{psig}\left(19.7 \mathrm{~kg} / \mathrm{cm}^{2}\right)$ and is equal to $30 \mathrm{psig}\left(21 \mathrm{~kg} / \mathrm{cm}^{2}\right)$ at the Khark Island station (Khark Database, 2011). The pipelines have an approximately $204 \mathrm{~m}$ head loss through the length. Hypothetical blowout from 30 inches OD light and heavy oil pipeline is considered at the first quarter of each pipeline with a hole with $5 \mathrm{~cm}$ diameter. In case of accident or corrosion at a similar location, an oil blowout with initial speed of $59 \mathrm{~m} / \mathrm{sec}$ will happen (according to mass conservation and Bernoulli equation) and 63,000 barrels per day would blowout from a hole with $5 \mathrm{~cm}$ OD. The criteria for selecting this condition and the related scenarios are: least time for hitting the spilled oil to the coast; maximum stranded oil to the coast and longest distribution along the shoreline. To compare the effects of light crude oil and heavy crude oil, blowout modeling of both types has been carried out separately as scenario No. 1 and 2. The comparison of light and heavy oil mass balance time-series is illustrated in Fig.3. Their mass balance time-series are almost similar. The evaporated oil in scenario No. 1 (light oil spill) is approximately 5\% (9450 barrels) more than the evaporated oil in scenario No. 2 (heavy oil spill). So in case of heavy oil released, there will be oil remaining in the water environment. On the other hand, the oil distribution in the marine environment is similar. Therefore only heavy oil blowout is considered hereafter.

Hypothetical blowout due to overall rupture from 52 inches OD heavy oil pipeline is considered at two locations. One when the blowout occurs at a point located at the first quarter of pipeline length and the other when it occurs at the middle of pipeline path. By the overall rupture of the 52 inches OD heavy oil pipeline, approximately 137,500 barrels per hour would blowout (Khark Database, 2011). Evaluation of the worst possible blowout from Khark pipelines are the criteria for selecting this condition and their scenarios. 
Pipelines have the advantage that can be controlled after the announcement of the blowout. For example it is possible to cease pipeline oil transportation, or sometimes if there is another pipeline in the path, oil can be transmitted by that. Announcing the oil blowout from a pipeline which is located on the seabed requires a permanent mass balance between two stations, or its oil slicks need to be observed by a vessel or to be observed on the shore. It is not possible to determine the blowout duration in Khark area, but available facilities to notice the blowout, allow approximately up to 3 days after the starting of the blowout depending on the rate of release; Therefore blowout duration less than 3 days was considered. To determine blowout duration from 30 inches OD pipelines, two blowout duration of 3 days and 1 day for heavy oil was considered in scenarios No. 2 and 3 respectively.

Winter has the worst condition of wind history and has the least content of oil evaporation. Therefore, the date of January 02, 1994 is selected as the initiate day of the blowout in all analyses.

Finally, based on aforementioned, 9 scenarios have been selected. The spill analysis of all scenarios covers the case study period from January 02, 1994 to February 01, 1994 using a simulation time step of 300 seconds and saving the results at a time interval of 1 hour. The model runs on a rectangular grid that each cell is $1.0 \mathrm{~km}$ North-South, and 1.0 km East-West.

\section{RESULTS AND DISCUSSIONS}

\section{Review Stage}

The mass balance time-series related to scenarios No. 1 to 6 are compared in Fig. 3. In these scenarios the major part of the evaporated heavy oil (15\% after 30 days) from water surface was observed in the first 6 days of the simulation. Significant part of the oil will pollute the environment by dispersion in the water column, depositing on the seabed and hitting the Khark area beach. The main factor in high volume of oil deposition on the seabed is the way out the oil from pipeline as the jet in high-speed (Ranjbar et al., 2011). This causes the intense entrainment and dispersion of the oil in the water column, so that only a small percentage of the spilled oil will be noticed on the water surface in the first day. As a result, in Khark area water (shallow water) this helps the deposition of more oil on the seabed as the sediment.

Here only results for scenario 2 is discussed. Fig. 4 shows a snapshot of the surface and subsurface distribution of heavy oil in scenario 2. For the first time oil hits the coast 5 days after the hypothetical blowout. Currents are the major component in the vertical distribution and the horizontal mixing of the oil in water column and wind has the minor influence on it. In this scenario (5 days after the blowout) the maximum oil concentration is $50 \mathrm{ppm}$ and the oil concentration contours are distributed in the entire water column. In scenario No. 2 also $8 \%(15,120$ barrels, or 2,100 tones) of the spilled oil stranded the coast 30 days after the hypothetical blowout. This leads to the maximum linear loading approximately $10 \mathrm{~kg} / \mathrm{m}$ on the shoreline. Major part of the spilled oil (40\%) was deposited on the seabed as sediment with maximum rate of $120 \mathrm{gr} / \mathrm{m}^{2}$.

First, scenario 2 was modeled without considering the potential effects of wind (Fig. 4). Oil moves in the surface and water column reciprocates with the currents in this simulation and as a result the spilled oil remains nearby the source. After 30 days, less than $1 \%$ of the spilled oil hit the North-West coast which is in the vicinity of the source. Therefore, wind is the major factor in the transport and spread of oil in the Khark area.

The sediment threats the Kharg seabed habitat, specially prawns. As mentioned above, major part of the spilled oil will be deposited on the seabed in scenario No. 2. In this scenario the maximum rates of sediment are $60 \mathrm{mgr} / \mathrm{m} 2$. No sediment is deposited on area \#3 in scenario 2. According to the high amount of oil dispersion in the water column, significant part of the oil droplets are moved by current in the upwind. This causes the slight oil sediment on seabed of area \#1 with maximum rate of $500 \mathrm{gr} / \mathrm{m} 2$.
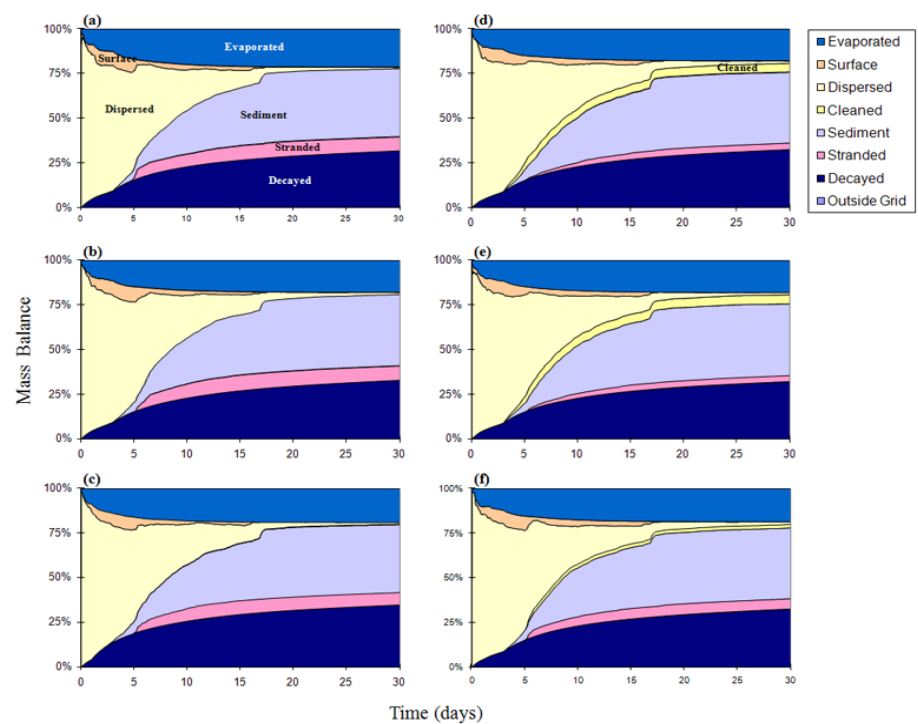

Fig. 3 Mass balance time-series for simulated blowout: (a) scenario No. 1; (b) scenario No. 2; (c) scenario No. 3; (d) scenario No. 4; (e) scenario No. 5; (f) scenario No. 6; (g) scenario No. 8; (h) scenario No. 9; (i) scenario No. 7.

\section{CONCLUSIONS}

The work reported here includes analyses of specific potential for oil blowout from pipelines which are located on the seabed between Iran mainland and Kharg Island. Results indicats that in Kharg area the major factor in the transport and spread of oil in the area is wind and the role of tidal currents is much less than wind. Due to wind conditions in Kharg area, the Kharg South-East coast has the maximum oil contamination potential. Also by changing the position of the oil blowout, the effect of oil on the Kharg area would be extremely changed. Significant part of the oil will pollute the environment by dispersion in the water column, depositing on the seabed and hitting the Khark area beach. The reason of high volume of deposited oil on the seabed in scenarios of blowout from a hole with $5.0 \mathrm{~cm}$ diameter is the high 
entrainment and dispersion of oil in the water column (due to high-speed outgoing of oil from pipeline as a jet) and Kharg shallow depth (less than 30m). In conclusion, the hypothetical spilled oil extremely threats the Kharg area environment and specially the prawns.

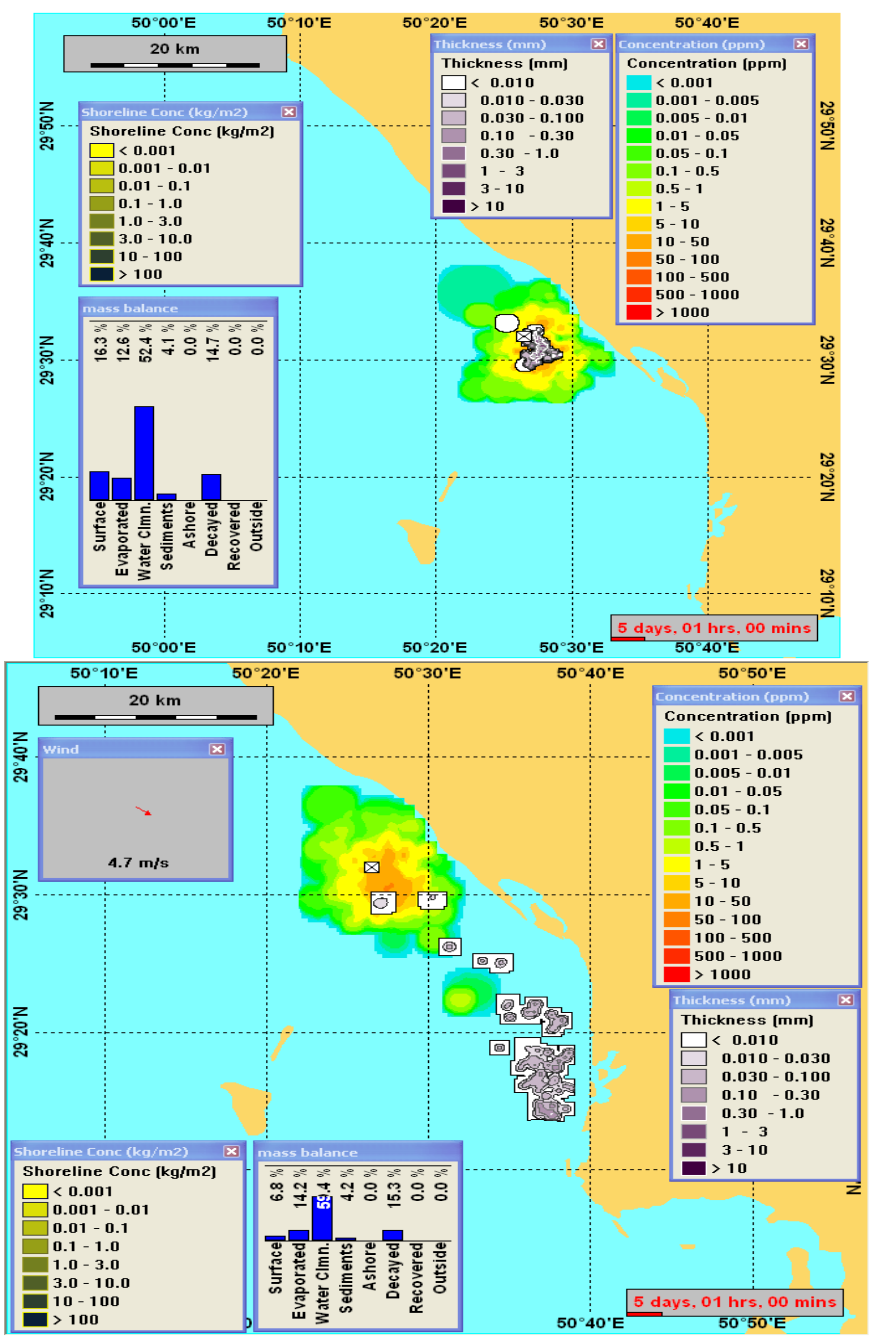

Fig. 4. Snapshot of surface and subsurface distribution of the total hydrocarbon concentra tions (THC) and surface oil 5 days after the hypothetical blowout in scenario No. 2 without considering the effects of wind (above) and with considering the effects of wind (below)

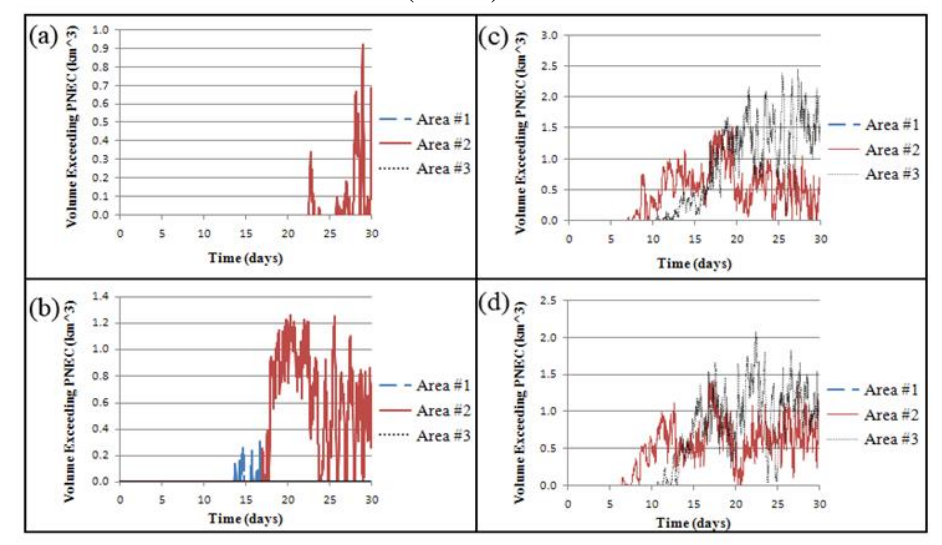

Fig. 5 Volume of water exceeding a Predicted No-Effect Concentration (PNEC) of 2 ppb: (a) scenario No. 2; (b) scenario No. 5; scenario No. 8; scenario No. 9

\section{ACKNOWLEDGMENT}

The authors would like to thank Professor Mark Reed and Dr. Boye HØverstad for their valuable supports. We would also like to acknowledge SINTEF research organization for providing us with MEMW-OSCAR model.

\section{REFERENCES}

[1] Aamo, O.M.; Reed, M.; Daling, P.S.; Johansen, O., (1993). A laboratory-based weathering model: PC version for coupling to transport models. In: Proceedings of the 1993 Arctic and Marine Oil Spill Program (AMOP) Technical Seminar, 617-626.

[2] Aamo, O.M.; Reed, M.; Downing, K.; (1996). Calibration, verification, and sensitivity analysis of the SINTEF oil spill contingency and response (OSCAR) model system (in Norwegian). SINTEF, Report 42.4048.00/01/96.

[3] Al-Rabeh, A.H.; Cekirge, H.M.; Gunay, N., (1991). Modeling the Fate and Transport of A-Ahmadi Oil Spill. Water, Air and Soil Pollution 65, 257-279.

http://dx.doi.org/10.1007/BF00479891

[4] Al-Rabeh, A. H.; Cekirge, H. M.; Gunay, N. (1992). Modeling the fate and transport of Al-Ahmadi oil spill. Water and Air Pollution, 65, 257279.

http://dx.doi.org/10.1007/BF00479891

[5] Badri, M.A.; Azimian, A. R., (2010). Oil spill model based on the Kelvin wave theory and artificial wind field for the Persian Gulf. Indian Journal of Marine Science 39 (2), 165-181.

[6] Daling, P.S.; Brandvik, P.J.; Mackay, D.; Johansen, O., (1990). Characterization of crude oils for environmental purposes. Oil \& Chemical Pollution 7, 199-224.

http://dx.doi.org/10.1016/S0269-8579(05)80027-9

[7] ECMWF (European Centre for Medium-Range Weather Forecasts), (2011). http://data.ecmwf.int/.

[8] Elhakeem, A.A.; Elshorbagy, W.; Chebbi, R., (2007). Oil Spill Simulation and Validation in the Persian Gulf with Special Reference to the UAE Coast. Water Air Soil Pollution 184, 243-254. http://dx.doi.org/10.1007/s11270-007-9413-1

[9] Farzingohar, M.; Zelina, Z.I.; Yasemi, M., (2011). Oil spill modeling of diesel and gasoline with GNOME around Rajaee Port of Bandar Abbas. Iranian Journal of Fisheries Sciences 10 (1), 35-46.

[10] Howlett, E.; Jayko, K.; Isaji, T.; Anid, P.; Gary, M.; Francois, S., (2008). Marine Forecasting and Oil Spill Modeling in Dubai and the Gulf Region. Dubai, COPEDEC 7.

[11] IOTC (Iranian Oil Terminals Company), (2011). Kharg island Database.

[12] IPMO (Iranian Port and Maritime Organization), (2011). Water Level Measurment Data Base

[13] Johansen, Ø., (2000). DeepBlow - A Lagrangian Plume Model for Deep Water Blowouts. Spill Science \& Technology Bulletin. Vol. 6, No. 2: 103-111. http://dx.doi.org/10.1016/S1353-2561(00)00042-6

[14] Lehr, W.; Cekirge, H., (1979). GULFSLICK I, a Computer Simulation of Oil Spill Trajectories in the Arabian Gulf. Research Institute, KFUPM, 25.

[15] Proctor, R.; Eliott, A.; Flather, R.A., (1994). Modelling tides and surface drift in the Persian Gulf-Application to the Gulf oil spill. Continental Shelf Research 14, 531-545. http://dx.doi.org/10.1016/0278-4343(94)90102-3

[16] Ranjbar, P.; Shafieefar, M.; Rezvandoost, J., (2011). Hydrodynamic study of accidental sub-sea oil blowout: case study of Kharg Island pipelines blowout. In: Proceedings of 10th Iranian Hydraulic Conference, University of Gilan, Gilan, Iran (In Persian).

[17] Ranjbar, P.; Shafieefar, M.; Rezvandoost, J., (2013). Modeling of Oil Spill and Response in Support of Decreasing Environmental Oil Effects Case Study: Blowout from Kharg Subsea Pipelines (Persian Gulf). International Journal of Environmental Research (In Press).

[18] Reed, M.; Turner, C.; Odulo, A., (1994a). The role of wind and emulsification in modeling oil spill and surface drifter trajectories. Spill Science and Technology 2, 143-157. http://dx.doi.org/10.1016/1353-2561(94)90022-1

[19] Reed, M.; French, D.; Rines, H. (1994b). Numerical simulation of biological effects of oil spills. J. Adv. Marine Technol. Conf., 11, 65-90.

[20] Reed, M.; French, D.; Rines, H.; Rye, H., (1995). A three dimensional oil and chemical spill model for environmental impact assessment. In: Proceedings of the International Oil Spill Conference 61-66. http://dx.doi.org/10.7901/2169-3358-1995-1-61 
[21] Sabbagh Yazdi, S.R., (2006). Coupled solution of oil slick and depth averaged tidal currents on three-dimensional geometry of Persian Gulf. International Journal of Environmental Science and Technology 2 (4), 309-317.

http://dx.doi.org/10.1007/BF03325891

[22] Smith;Sandwell,(1994,1997).

http://topex.ucsd.edu/marine_topo/mar_topo.html.

[23] United States Defense Mapping Agency's digital chart of the world database.http://www.nlh.no/ikf/gis/dcw/. 